\title{
дискУССИИ
}

www.volsu.ru

DOI: https://doi.org/10.15688/jvolsu2.2019.4.19

UDC 811.161.1'35

Submitted: 04.04.2019

LBC 81.411.2-65

Accepted: 03.10.2019

\section{ORTHOGRAPHIC NORM AND GRAMMATICAL HOMONYMY}

\author{
Svetlana Yu. Kharchenko \\ Volgograd State University, Volgograd, Russia
}

\begin{abstract}
The article deals with the relevant linguistic issue of correlation between word spelling and the distinction of units belonging to different grammatical classes. The concepts of word and part of speech are contrasted. The author has revealed the peculiarities of lexical units functioning in written speech, which enables their part-of-speech status identification. The analysis of criteria, suggested by the linguists for differentiation of homonymous adverbs, preposition-and-case-form combinations, and derivative prepositions resulted in proposing a procedure of consecutive operations, accomplished to identify the part-of-speech status of grammatically homonymous words. The results of the linguistic experiment show how in speech practice native speakers solve the problems of part of speech determination and establishing the spelling of such words. It was revealed that the methods for distinguishing grammatical homonyms used by recipients, in many cases, do not lead to the correct solution. The existing codified guidelines are not applied while writing, as spelling of the major part of grammatically homonymous words does not meet the requirements of the norm. To solve the problem under consideration, it is necessary to adjust the content of spelling rules and change the spelling of a number of words, where traditional spelling principles are reflected.

Key words: Russian language, linguistic norm, orthographic norm, grammar norm, part of speech, grammatical homonyms.

Citation. Kharchenko S.Yu. Orthographic Norm and Grammatical Homonymy. Vestnik Volgogradskogo gosudarstvennogo universiteta. Seriya 2. Yazykoznanie [Science Journal of Volgograd State University. Linguistics], 2019, vol. 18, no. 4, pp. 248-258. (in Russian). DOI: https://doi.org/10.15688/jvolsu2.2019.4.19

УДК 811.161 .1 '35

Дата поступления статьи: 04.04.2019

ББК 81.411.2-65

Дата принятия статьи: 03.10.2019
\end{abstract}

\section{ОРФОГРАФИЧЕСКАЯ НОРМА И ГРАММАТИЧЕСКАЯ ОМОНИМИЯ}

\author{
Светлана Юрьевна Харченко \\ Волгоградский государственный университет, г. Волгоград, Россия
}

\begin{abstract}
Аннотация. Статья посвящена актуальной лингвистической проблеме связи между орфографическим оформлением слов и разграничением единиц, относящихся к разным грамматическим классам. Рассмотрено соотношение понятий «слово» и «часть речи». Установлены особенности функционирования лексических единиц в письменной речи, позволяющие установить их частеречный статус. В результате анализа выдвинутых лингвистами критериев дифференциации омонимичных наречий, предложно-падежных сочетаний и производных предлогов автором определен порядок последовательного установления частеречной принадлежности слов, находящихся в отношениях грамматической омонимии. Описаны итоги проведенного пилотного лингвистического эксперимента, которые демонстрируют то, как в речевой практике носители языка решают задачи отнесения слова к той или иной части речи (наречие, существительное, предлог) и о установления его орфографии. Выявлено, что приемы разграничения грамматических омонимов, использ зуемые реципиентами, во многих случаях не приводят к правильному решению, существующие кодифицированные установки не находят применения у пишущих, поскольку орфографическое оформление большей части слов, являющихся грамматическими омонимами, не отвечает требованиям нормы. Определены пути : преодоления рассматриваемой проблемы: корректировка содержания орфографических правил и изменение орфографического облика ряда слов, отражающего традиционный принцип правописания.
\end{abstract} ()) 
Ключевые слова: русский язык, языковая норма, орфографическая норма, грамматическая норма, часть речи, грамматические омонимы.

Цитирование. Харченко С. Ю. Орфографическая норма и грамматическая омонимия // Вестник Волгоградского государственного университета. Серия 2, Языкознание. - 2019. - Т. 18, № 4. - С. 248-258. - DOI: https://doi.org/10.15688/jvolsu2.2019.4.19

Традицию нельзя превращать в нечто незыблемое, священное, ибо она хороша в том случае, когда облегчает миллионам овладевать правописанием, и она очень плоха, когда вносит излишние трудности.

Е.М. Галкина-Федорук

\section{Введение}

Вопросы орфографического оформления слов, несмотря на существование кодифицированных нормативных установок, продолжают оставаться актуальными и для рядовых носителей русского языка, и для лингвистов. Носители языка в практике письменной коммуникации нередко оказываются в ситуации выбора написания слова из нескольких возможных вариантов и в зависимости от ряда факторов (уровня сформированности языковой компетенции, развития языкового чутья, степени начитанности и др.) принимают решение, отдавая предпочтение правильному или неправильному варианту. Лингвисты свою задачу видят в создании таких орфографических правил, которые максимально оптимизировали бы выбор пишущих при сохранении адекватного отражения языковых связей.

От грамматических характеристик обозначаемых на письме единиц и прежде всего от их частеречной принадлежности зависит решение большей части вопросов одного из разделов русской орфографии - слитных / раздельных / дефисных написаний. Для рядовых носителей языка особую сложность представляют ситуации, требующие разграничения грамматических омонимов и применения орфографических нормативов, нарушающих нормы графики. Предметом рассмотрения в статье послужила орфографическая норма, связанная с дифференциацией омонимичных единиц с позиций морфологических классов.

\section{Исходные положения}

Рассматривая письмо как саморазвивающуюся систему [Бешенкова, 2016; Wildgen,
1990], лингвисты признают, что нормализаторская деятельность в отношении кодификации может проводиться различными способами: совершенствованием правил, изменением графического облика отдельных слов, введением вариантов орфографического оформления лексических единиц. По мнению Е.В. Бешенковой, в структурно-системной части письма, противопоставленной его асистемной части, варианты в написании «возникают в предсказуемых точках, обусловленных антиномиями системы» [Бешенкова, 2016, с. 36], в частности, в случаях употребления единиц, относящихся к грамматическим омонимам. В таких ситуациях пишущие нередко задаются вопросом: сколько слов и какую часть речи (или сочетание каких частей речи) им предстоит отразить на письме?

Проблема соотнесения понятий «слово» и «часть речи» языковедами решается неоднозначно, что обусловлено различиями в выборе критериев классификации лексем по частям речи. В истории развития грамматических учений прослеживаются несколько подходов к пониманию сущности частей речи и принципов их выделения в языках различных типов, но, по справедливому замечанию Л.В. Щербы, важна не сама классификация, а установление того, «...под какую общую категорию подводится то или иное лексическое значение в каждом отдельном случае» [Щерба, 1957, с. 64]. Одно и то же слово, считает ученый, может материально фигурировать в разных категориях (например, вблизи может быть наречием или предлогом), поэтому классификация всех слов в языке по частеречной принадлежности не представляется возможной и необходимой, относить слово к тому или иному грамматическому классу следует в каждой конкретной ситуации.

Развитие рассматриваемого вопроса иногда приводит лингвистов к выводу о том, что понятие сло́ва шире понятия части речи, поскольку, по словам В.И. Куракова, в процессе транспозиции «не слово и не часть речи 
переходят в другую часть речи, а лишь лексическое меняет свою грамматическую принадлежность» [Кураков, 1998, с. 93]. Именно лексема, по мнению исследователя, переходит из одной части речи в другую, образуя при этом «единство того же самого лексического, но уже с иной частью речи» [Кураков, 1998, с. 93], и весьма не бесспорно называть это новообразование новой лексической единицей, в связи с тем что изменение части речи ведет к изменению только отношений, в которые может вступать эта же лексема, поэтому, например, бурить и бурение, приходит к выводу ученый, - это две грамматические формы одной лексемы.

Мы придерживаемся иного взгляда: план выражения лексических единиц, относящихся к разным частям речи, может совпадать, но различия семем (а они обязательно будут наблюдаться у слов разных частей речи) не позволяют объединять их в рамках одного слова. Любые омокомплексы, не обладающие тождественными планами содержания, по нашему мнению, представляют разные слова.

Благодаря трудам В. В. Виноградова, с середины XX в. традиционными критериями определения частеречной принадлежности лексической единицы стали считаться характер синтаксического употребления, характер номинации и система грамматических форм [Виноградов, 2001, с. 41-42]. Однако в составленной самим ученым классификации к частям речи относятся только знаменательные слова, а междометия, модальные слова и служебные (частицы речи) в их круг не входят, поскольку не обладают способностью номинации. Взяв за основу традиционную типологию слов (десять частей речи: имена существительные, прилагательные, числительные, глагол, местоимение, наречие, категория состояния, предлог, союз, частица; а также междометия и звукоподражательные слова), обратим внимание на условность ее традиционности. В языке, как непрерывно развивающейся системе, состав той или иной категории слов может меняться, что связано с особенностями функционирования входящих в нее единиц. Первоначально значимый для установления части речи синтаксический критерий со временем становится неосновным, на первый план выходят морфологические при- знаки, но при развитии вторичных синтаксических функций у слова могут происходить изменения в грамматических характеристиках, что, как следствие, приводит к его расщеплению. Для обозначения такой лексической единицы, которая способна выступать в функции разных частей речи, но является единицей абстрактной, Л.В. Малаховским предложен термин «гиперлексема» [Малаховский, 1990, с. 219], однако для рядовых носителей языка он представляется неактуальным.

Учитывая неоднозначные решения вопроса о соотношении понятий «слово» и «часть речи», принимаем следующие трактовки: слово - это единица языка, конструируемая совокупностью лексического и грамматического компонентов; частеречная принадлежность одна из составляющих грамматического компонента; каждой знаменательной части речи присуще свое общекатегориальное значение, которое выражается в определенных морфологических категориях; слова служебных частей речи классифицируются в соответствии с функциональным критерием.

\section{Грамматическая омонимия и синхронная транспозиция}

Вопрос о грамматических омонимах связан с дискуссией о синхронии и диахронии в языке. Если признать, что синхрония - это фрагмент диахронии, имеющий некоторую длительность, а язык развивается непрерывно, то логично предположить, что и в синхронии можно наблюдать процесс образования грамматических омонимов. В рамках настоящей статьи термины «грамматические омонимы» и «функциональные омонимы» употребляются как синонимичные, хотя, несомненно, в исследованиях филологов аргументируется необходимость в их различении [Авдина, 2013, с. 205; Ахманова, 1957, с. 165]. Под грамматическими (функциональными) омонимами нами понимаются этимологически родственные слова (в отдельных случаях слова и словоформы), совпадающие по звучанию, но различающиеся частеречной принадлежностью.

Кроме явных случаев грамматической омонимии лингвисты отмечают существование в языке и речи единиц, содержащих при- 
знаки разных грамматических классов. Подобные явления находятся в зоне переходности и характеризуются синкретизмом определенных свойств. По мнению В.В. Бабайцевой, при синхронной переходности, то есть переходности в системе языка в определенный временно́й период, связи между центральными (типичными) категориями создают зону синкретизма с периферийными и промежуточными звеньями [Бабайцева, 2000, с. 27]. В разработанной ею шкале переходности между крайними звеньями А и Б (четко противопоставленными грамматическими омонимами) могут находиться промежуточные звенья Аб, АБ, аБ (относящиеся к ним элементы в равной (АБ) или разной (Аб, аБ) степени обладают признаками каждого из компонентов омонимической оппозиции). Например, синхронную переходность в современном русском языке (как и в другие временные периоды) можно проследить у словоформ существительных и омонимичных им наречий: Любуюсь вечером (звено А - сущ.) - Засыпаю поздним вечером (звено Аб - сущ. с наречным признаком - обстоятельственная функция) - Читаю книги вечером (по мнению В.В. Бабайцевой, это звено АБ, в котором прослеживается равновесие признаков существительного и глагола; в общепринятой трактовке это наречие).

Наибольшую сложность в определении степени перехода из одного грамматического класса в другой представляют омокомплексы, включающие 1) предложно-падежные сочетания в роли обстоятельств и наречия; 2) предложно-падежные сочетания, наречия и предлоги. Компоненты этих омокомплексов встречаются в письменной речи весьма часто: Россияне помоложе, для которых банковские карты и электронные кошельки давно не в новинку, захаживают на почту изредка... (Комсомольская правда, 08.07.2015); Русский господин нехотя удалился с бокалами на отлете (Коммерсантъ, 06.05.2016); Их действительно кормят на убой (Комсомольская правда, 15.07.2008); В России можно будет купить топливо на заправках в рассрочку (Коммерсанть, 18.09.2019); Двор и его обитатели принимают семейство в штыки, а всему виной вздорный нрав новоселов (Комсомольская правда, 17.06.2010);
Трубу тянули в складчину (Российская газета, 19.06.2019); Кстати, и сама учительница, и одноклассники в иутку называют тезку знаменитого голландиа Гусь (Комсомольская правда, 29.03.2018); Слушает Дарья, а у самой сердияе на изорвь идет (Е. Кулькин); Случалось, дорога ила навздым и там крепчала под солнцем и ветром (Ю. Нагибин).

Анализ исследуемых нами языковых единиц позволил отнести каждую из них к одному из четырех типов.

1. Наречия, в современном русском языке уже не соотносимые с предложно-падежными сочетаниями (например, без умолку, без удержу, без просыпу, с пантальку, до зарезу, до упаду, на ощупь, на скаку, в охотку).

2. Наречия, функционирующие в современном русском языке параллельно с омонимичными предложно-падежными сочетаниями (на дом, до смерти, до отказа, на миг, на славу, на вид, в охапку, с маху, в сердцах, в головах, в рознииу, на износ, по праву, по совести и др.).

3. Предложно-падежные сочетания, не имеющие в современном русском языке омонимичного наречия, сформировавшегося путем адвербиализации (до кониа, без внимания, на мгновение и др.).

4. Предлоги, омонимичные наречиям и сформировавшиеся на базе адвербиализованных сочетаний (без ведома, вслед за, вдали от и др.).

\section{Разграничение омонимичных структур в грамматике}

Вопрос установления морфологического статуса лексических единиц и различения грамматических омонимов признавался актуальным со времени создания первых трудов о грамматическом строе русского языка. В середине XVIII в. М.В. Ломоносов в $§ 125$ «Российской грамматики» указывал на необходимость дифференциации слитных и раздельных предлогов (слитные предлоги позже стали называть приставками). Как отметил ученый, на практике многие «погрешают» в их употреблении и на письме «слитие... сплошь видно: вдом $\mathbf{t}$, надгорою, изокна» [Ломоносов, 1755, с. 59]. Вероятно, слитное 
написание в подобных случаях объясняется влиянием господствовавшего ранее слитного письма в рукописях (scriptio continua) и трудностью различения предлогов и приставок.

Однако, как писал М. В. Ломоносов, требуется помнить, что слитные предлоги остаются в составе слова во всех его грамматических формах, а раздельные предлоги сохраняются только в определенных падежах; при глаголах всегда используются предлоги слитные; наречиями становятся сочетания предлогов с существительными (и пишутся слитно), если предлог употреблен не с присущей для него падежной формой (вдругъ) или перед именем, в других формах не использующемся (вкось), а также при изменении значения (вм tcm t) [Ломоносов, 1755, с. 59-60]. Предложенные критерии разграничения наречий и предложно-падежных сочетаний находили применение в практике обучения грамматике вплоть до середины XX в., несмотря на то, что в процессе становления русской орфографии рекомендации по этому вопросу высказывались практически всеми авторами грамматик и учебников русского языка (см. об этом, например: [Харченко, 2002]).

При решении вопроса о дифференциации наречий и предложно-падежных сочетаний необходимо отличать случаи завершившегося процесса адвербиализации и те случаи, когда этот процесс на современном этапе развития языка еще длится и рядовому носителю языка сложно определить его стадию.

Открытым остается вопрос, можно ли относить слово к классу имен существительных, если в речи оно функционирует только в обстоятельственной функции и только в составе предложно-падежных сочетаний. Материалы толковых словарей современного русского языка не всегда последовательны в отражении этого вопроса. Так, в «Толковом словаре русского языка с включением сведений о происхождении слов» (2007 г.) удерж, умолк, упад, кондачок, пантальк, просып представлены как существительные, но лексические значения этих единиц в словаре не приводятся, фиксируется только семантика сочетаний: без удержу - 'не сдерживаясь, неудержимо' (c. 1019); без умолку - 'не умолкая, не затихая' (с. 1027); до упаду - 'до полного изнеможения' (с. 1029); с кондачка - 'не подгото- вившись, несерьезно, легкомысленно' (с. 357); с пантальку (сбить(ся) с пантальку) 'привести (прийти) в растерянность, лишить (лишиться) соображения' (с. 611); без просыпу (без просыпа $)$ - 1) без просыпу спать - долго и крепко, 2) без просыпу пить - о беспробудном пьянстве (с. 767).

$\mathrm{B}$ «Толковом словаре служебных частей речи русского языка» Т.Ф. Ефремовой (2001 г.), фиксирующем помимо собственно служебных частей речи наречия и предикативы, находим словарные статьи с пометой качественнообстоятельственное наречие, разговорное у единиц без удержу, без умолку, без просыnу и без nросыпа, до упаду, с кондачка. Толкование наречия $c$ nантальку в этом словаре от сутствует.

В «Морфемном словаре наречий русского языка» Ю.Н. Гребеневой (2017 г.) анализируемые единицы тоже зафиксированы, причем у некоторых из них орфографический облик отражается и в соответствии с современной кодификацией нормы, и с пометой «устаревшее написание»: без просыпу (с. 29), без удержу (с. 32), без умолку и безумолку (устар.) (c. 32), до упаду (с. 150). Наречия с кондач$к а$ и $с$ панталыку не представлены. В этом словаре отмечены случаи изменения написания с дефисного на слитное: вовремя и вовремя (устар.) (с. 78); с дефисного на раздельное: во веки веков и вовеки-веков (устар.) (с. 77-78), на днях и на-днях (устар.) (c. 251), на нет и на-нет (устар.) (с. 260), под руку и под-руку (устар.) (с. 387), по сердиу и по-сердиу (устар.) (с. 425), только что и только-что (устар.) (с. 553); с раздельного на слитное: вкруговую и в круговую (устар.) (с. 69), внаклон и в наклон (устар.) (с. 72), вполсвета и в полсвета (устар.) (c. 90), вполуоборот и в полуоборот (устар.) (с. 90), вприхлюпку и в прихлюпку (устар.) (с. 93), вразноголосииу и в разноголосииу (устар.) (с. 96), вразнос и в разнос (устар.) (с. 96), навскидку и на вскидку (устар.) (с. 248), напеременку и на переменку (устар.) (с. 262), напрокат и на прокат (устар.) (с. 265), сплеча и с плеча (устар.) (с. 523); со слитного на раздельное: без толку (с. 32) и бестолку (устар.) (с. 41); под мышками и подмышками (устар.) (с. 383-384), под мышки и подмышки (устар.) (с. 384), под мышкой и под- 
мышикой (устар.) (с. 384), под мышику и подмылику (устар.) (с. 384); со слитного на дефисное: мало-мальски и маломальски (устар.) (с. 226), по-прежнему и попрежнему (устар.) (с. 419).

Нам представляется правомерным единицы без удержу, без умолку, до упаду, с кондачка, с пантальку, без просыпу считать наречиями, поскольку имя существительное (как и любая другая часть речи, имеющая в составе парадигмы определенное количество словоформ) «опознается» по начальной форме. Парадигма существительных удерж, умолк, упад, кондачок, панталык, просып разрушилась, но в некоторых словарях современного русского языка продолжает фиксироваться их начальная форма без кодификации значения. В подобных случаях можно говорить об утрате языком лексической единицы - имени существительного и сформированности в результате адвербиализации новой лексической единицы - наречия, орфографическое оформление которого пока решается в соответствии с традиционным принципом. Итак, отсутствие начальной формы и большей части падежных форм свидетельствует о завершении процесса перехода существительного в наречие.

Отметим другие особенности функционирования лексических единиц, помогающие установить их частеречный статус.

1. Предлог не употребляется в предложении самостоятельно, без именной словоформы в косвенном падеже (ср.: Лагерь расположился вблизи дороги и $\mathrm{Mbl}$ увидели находящуюся вблизи постройку). В семантическом отношении слово вблизи во втором предложении предполагает контекстное пояснение, вблизи чего / кого находится строение (поэтому по шкале переходности В.В. Бабайцевой, возможно, этот случай не будет последним звеном в цепи), но по формальному показателю это несомненное наречие в современном русском языке.

2. Наречие, будучи в предложении обстоятельством, не может иметь при себе зависимое дополнение (ср.: Вдали показался парус и Вдали от нас пропльла акула). Если признать существование многозначных членов предложения, то в зоне синкретизма могут находиться случаи, когда обстоятельство, выраженное существительным, имеет при себе определение, например, в предложении Просыпаюсь ранним утром словоформа ранним выполняет функцию определения, согласуясь с обстоятельством утром (сущ.), но дополнения в подобных ситуациях быть не может.

3. Одно из средств дифференциации наречий и омонимичных им предложно-падежных сочетаний - фонетические различия, а именно изменение места ударения. Префиксы (из предлогов) и в ряде случаев суффиксы (из флексий) в составе наречий перетягивают ударение на себя: во́время (ср.: во вре́мя), за́мужем (ср.: за му́жем), по́боку (ср.: по бо́ку), на́голову (ср.: на го́лову), о́троду (ср.: от ро́ду), до́ смерти (ср.: до сме́рти), за́ полночь (ср.: за по́лночь), на́ дом (ср.: на до́м), вплотну́ю (ср.: в пло́тную), втиху́ю (ср.: в ти́хую) и др. Кроме того, значимым является и характер звука, с которого начинается вторая часть сочетания (при предлогеприставке на согласный). Если второй компонент начинается с гласного, то рекомендуется дистантное его положение по отношению к первому, а соответственно, и признание в данном случае предложно-падежного сочетания, а не наречия.

4. Существуют определенные различия в лексических значениях грамматических омонимов. Разрыв в семантике наречия и существительного ощущается в большей степени в тех случаях, когда на современном этапе носители языка не прослеживают мотивационные связи между ними ( пантальку, с кондачка). Однако, сравнивая, например, семантику наречий, появившихся в результате адвербиализации, и «наречных сочетаний», оформляющихся на письме аналитически, исследователи нередко говорят о метафорическом употреблении существительных в таких сочетаниях. В частности, единицы 8 сердияах, за глаза, в корне, в лицуо, в пику рассматриваются как предложно-падежные сочетания, в которых сердиуе, глаз, корень, лицо, пика являются существительными, функционирующими в переносном значении [Волошина, 1994, с. 82].

5. Изменения на уровне семантики приводят к изменениям на грамматическом уровне: наречия выражают значение при- 
знаковости действия или другого признака, а не значение предметности. Один из способов различения омонимичных структур - возможность замены синонимом, имеющим то же общекатегориальное значение. Однако было бы неверным признать прием синонимической замены [Галкина-Федорук, 1954, с. 16] универсальным, так как синонимичными могут быть слова, относящиеся к разным частям речи.

6. Весьма распространенное мнение о том, что существование хотя бы двух падежных форм в парадигме доказывает наличие имени существительного в языке (без огляд$\kappa и-c$ оглядкой, на карачки - на карачках), на наш взгляд, не вполне обоснованно: отсутствие в словарях кодифицированной формулировки лексического значения начальной формы существительного свидетельствует об утрате языком ранее функционировавшего имени.

7. Оригинальный прием различения наречий и омонимичных структур, основанный на способности словоформы быть членом замкнутого или незамкнутого ряда, был предложен М.В. Пановым. Если оставшаяся после отделения приставки-предлога часть может рассматриваться как имя существительное и данное предложно-падежное сочетание входит в незамкнутый ряд сочетаний такого типа, то, считает лингвист, полной адвербиализации не произошло и нужно говорить об употреблении падежной формы существительного с предлогом [Панов, 1964, с. 115]. Например, сочетание в полоску входит в открытый ряд материя в полоску, в елочку, в квадрат, в колокольчик и т. д., а сочетание в головах - член замкнутого ряда лежит в головах, в ногах, но невозможно: в руках, в спинах и т. д.

8. Возможность вставки согласованного определения между предлогом и существительным позволяет, по мнению многих, отграничить их от наречий. Такое утверждение было зафиксировано в первом издании «Правил русской орфографии и пунктуации» [Правила..., 1956, с. 45]. Представляется лингвистически некорректной формулировка «если можно вставить», так как семантическая близость омонимичных наречий и имен существительных может оставаться явной, и при отсутствии определения единица будет квали- фицироваться как наречие, а при его наличии как имя существительное: ударил с маху ударил со всего маху, коня остановит на скаку - остановит на полном скаку. Однако есть и более категоричная точка зрения: вставкой-определением следует считать не любое слово. В частности, в примерах внизу - в самом низу, вверху - в самом верху, на ходу - на полном ходу, на миг - на один миг, на днях - на этих днях вставками могут быть только определенные слова, что говорит о мнимой проницаемости между компонентами наречий [Шанский, 1964, с. 48]. В новой редакции кодифицированного свода правил данный критерий для различения грамматических омонимов не предлагается [Правила..., 2006, с. 141-148].

Учитывая все рассмотренные критерии и приемы дифференциации омонимичных структур, предлагаем использовать следующую последовательность проверки грамматических признаков слов:

1. Употребляется в современном русском языке слово с другим препозитивным компонентом, без него или нет? (Если нет, то это наречие).

2. Имеет часть без препозитивного компонента начальную форму или нет? (Если нет, то это наречие).

3. Входит в сочетание с именем существительным / личным местоимением в косвенном падеже или нет? (Если да, то это предлог).

4. Имеет при себе согласованное определение (не из числа строго ограниченных фразеологизированных) или нет? (Если да, то это предложно-падежное сочетание).

5. Входит в замкнутый ряд сочетаний такого же типа или нет? (Если да, то это наречие, если нет, то - предложно-падежное сочетание).

\section{Грамматические омонимы в сознании носителей языка}

Для выявления того, осознают ли носители русского языка связь между орфографическим оформлением грамматических омонимов и их частеречной принадлежностью, был проведен пилотный лингвистический эксперимент. В нем добровольно участвовали 
108 человек. Все участники - студенты Волгоградского государственного университета разных курсов и направлений подготовки, в том числе и направления «Филология». Эксперимент проводился в учебной аудитории, время выполнения заданий ограничивалось 30 минутами.

Эксперимент проводился в два этапа.

Материал для первого этапа представлял собой 18 предложений, целенаправленно составленных для проведения эксперимента. Графически маркированными шрифтовым выделением в предложениях были слова (сочетания), являющиеся компонентами омонимических пар (рядов): вдали (наречие) - вдали от (предлог) - в дали (существительное с предлогом); вглубь (наречие) - вглубь (предлог) - в глубь (существительное с предлогом); вбок (наречие) - в бок (существительное с предлогом); до отказа (наречие) - до отказа (существительное с предлогом); навстречу (наречие) - навстречу (предлог) - на встречу (существительное с предлогом); навыпуск (наречие) - на выпуск (существительное с предлогом); в шутку (наречие) - в шут$\kappa y$ (существительное с предлогом); в иелях (предлог) - в иелях (существительное с предлогом) и др. Участники эксперимента должны были указать, к какому грамматическому классу слов относятся выделенные лексические единицы, и самостоятельно определить правильный вариант их написания.

На втором этапе эксперимента участникам было предложено написать словарный диктант (26 слов), реципиенты были предупреждены о том, что все слова в нем являются наречиями.

Были получены следующие данные.

С заданием первого этапа полностью не справился ни один из участников; наибольшее количество ошибочных ответов было в тех случаях, когда функциональная омонимия прослеживалась у слов трех частей речи (92\% ошибок) и когда орфографическое оформление омонимов идентично, то есть они пишутся слитно или раздельно независимо от частеречной принадлежности (88 \%).

Проверка выполнения задания второго этапа показала следующее. Студенты орфографически верно (в части слитного / раздельного написания) отразили на письме толь- ко наречия сверху и позавчера. Единичные случаи ошибок (до 2) в написании слова воистину (во истину и во-истину). $10 \%$ респондентов ошиблись в орфографическом облике наречий подчистую и в шутку; 13,4 \% - в словах с горя и наотмашь; $15 \%$ - в наречии в обнимку; 16,3\% написали слитно до упаду и до отказа; $25 \%$ использовали дефис в отражении на письме наречия бок о бок (кроме того, встречались случаи написаний бок обок, бок об бок, бок в обок). Орфография остальных наречий вызвала значительные затруднения: 30 \% участников эксперимента ошиблись в слитном / раздельном / дефисном написании слов точь-в-точь (кроме раздельного варианта точь в точь, встретились точь-в точь и точь-вточь) и на скаку; $33,4 \%$ - в наречиях наотлет, поначалу (по началу $и$ по-началу), след в след (разнообразные варианты: след-в-след, след вслед, вслед-вслед, вслед вслед, след-вслед, в след в след); $41,7 \%$ - в словах дотемна и наудалую; $43,4 \%$ - в наречиях навыпуск и на плаву; $48,3 \%$ не знают правильного облика первонаперво (кроме раздельного написания перво наперво и перво на перво, встретились перво-на-перво, перво-на перво, перва-наперва, перво наперва, перва на перво, перва наперво, перва наперва, первонаперво); $50 \%$ - пишут слитно $c$ nерепугу. Количество студентов, допустивших ошибку в написании слов наутро и поодиночке, превысило число знающих нормативный вариант $(53,4$ \% и $63,4 \%$ соответственно полагают верным раздельное оформление приставок в этих словах). Наибольшую сложность для обучающихся представляет выбор правильного отражения на письме наречий на ошупь (70 \% ошибившихся) и с панталыку $(71,7 \%)$. Незнание фразеологизма сбить с пантальку проявилось не только в слитном написании наречия (в этом случае оно как раз абсолютно оправдано: на современном этапе имя существительное панталык не употребляется, другие его формы не сохранились даже в устойчивых сочетаниях, носители языка не осознают его как компонент грамматической омонимии), но и в ошибках другого типа: спонтолькку, вспанталыку, спонтальгу, спонтольгу, спанталыгу, спантолыгу. Мнение лингвистов о том, что в рассматриваемом фразеоло- 
гизме сильноуправляемый глагол сбить «провоцирует понимание этого сочетания как предлог + уникальное управляемое существительное» [Кузьмина, 2010, с. 64], для рядовых пишущих не представляется актуальным.

В результате обобщения полученных данных можно констатировать, что носители языка, даже профессионально ориентированные студенты-филологи, испытывают затруднения при установлении частеречной принадлежности слов.

Анализ итогов эксперимента наглядно подтверждает мнение Л.П. Крысина о наличии несовпадений возможностей системы языка, нормативных установок и речевой практики [Крысин, 2010, с. 12]. Подобная ситуация сложилась и в части слитных / дефисных написаний сложных существительных и сложных прилагательных (см. об этом: [Кузьмина, 2010; Сидорова, 2018]), фрагментарно касающихся вопроса грамматической омонимии.

\section{Выводы}

Грамматические омонимы на уровне частеречной принадлежности являются разными словами, несмотря на то, что может отчетливо прослеживаться близость их лексических значений и фонетического оформления. Синтаксические функции при синхроническом рассмотрении не могут выступать, на наш взгляд, в качестве основного критерия определения частеречной принадлежности слова, ибо слова различных грамматических классов могут выполнять идентичные функции, но установление валентностных особенностей тех или иных единиц в конкретных случаях употребления может помочь разграничению омонимичных слов и сочетаний. Процесс формирования грамматических омонимов непрерывен, он наблюдается и в современном русском языке, у некоторых лексических единиц однозначно определить стадию перехода из одной части речи в другую, степень сформированности всех признаков «нового» грамматического класса представляется весьма сложным. Именно поэтому возникают затруднения при решении вопроса о слитном / раздельном / дефисном написании слов, относящихся к омонимичным структурам. Критерии дифференциации наречий, предлож- но-падежных сочетаний и предлогов должны быть максимально формальными, чтобы пишущие могли использовать их до применения орфографических правил. Требуется корректировка лингвистического содержания правил в части слитного / дистантного отражения слов на письме, поскольку существующие нормативные установки, как показали результаты проведенного эксперимента, не используются носителями языка даже в случаях, когда частеречная принадлежность слов однозначно определена.

\section{СПИСОК ЛИТЕРАТУРЫ}

Авдина А. И., 2013. Грамматическая омонимия как специфическое явление языка // Вестник Челябинского государственного педагогического университета. № 9. С. 204-211.

Ахманова О. С., 1957. Очерки по общей и русской лексикологии. М. : Учпедгиз. 295 с.

Бабайцева В. В., 2000. Явления переходности в грамматике русского языка. М. : Дрофа. 640 с.

Бешенкова Е. В., 2016. Вариативность, узуальная норма и политика нормализаторов // Сибирский филологический журнал. № 3. С. 35-42. DOI: $10.17223 / 18137083 / 56 / 3$.

Виноградов В. В., 2001. Русский язык : (Грамматическое учение о слове). 4-е изд. М. : Рус. яз. 720 с.

Волошина Т. А., 1994. Правописание наречий в русском языке: история и современное состояние. Ростов н/Д : Изд-во Рост. гос. ун-та. 112 с.

Галкина-Федорук Е. М., 1954. К вопросу об омонимах в русском языке // Русский язык в школе. № 3. С. 14-19.

Крысин Л. П., 2010. Проблема соотношения языковой системы, нормы и узуса // Современный русский язык : Система - норма - узус / отв. ред. Л. П. Крысин. М. : Яз. слав. культур. С. 9-28.

Кузьмина С. М., 2010. Система, норма и узус в фонетике и письме // Современный русский язык : Система - норма - узус / отв. ред. Л. П. Крысин. М. : Яз. слав. культур. С. 29-67.

Кураков В. И., 1998. В плену заблуждений, или О некоторых противоречиях в теории частей речи // Вестник Волгоградского государственного университета. Серия 2, Филология. Вып. 2. С. 92-94.

Ломоносов М. В., 1755. Российская грамматика. СПб. : Императ. Акад. наук. 213 с.

Малаховский Л. В., 1990. Теория лексической и грамматической омонимии. Л. : Наука. 239 с.

Панов М. В., 1964. О слитных и раздельных написаниях // Вопросы русской орфографии. М. : Наука. С. 100-119. 
Правила русской орфографии и пунктуации, 1956. М. : Учпедгиз. 176 с.

Правила русской орфографии и пунктуации. Полный академический справочник, 2006. М. : Эксмо. 480 с.

Сидорова Е. Г., 2018. Проблемы и противоречия кодификации сложных прилагательных в русском языке // Вестник Волгоградского государственного университета. Серия 2, Языкознание. Т. 17, № 4. C. 68-80. DOI: https://doi.org/10.15688/jvolsu2. 2018.4.6.

Харченко С. Ю., 2002. Процесс становления орфографии наречий // Вестник Волгоградского государственного университета. Серия 2 , Языкознание. Вып. 2. С. 108-114.

Шанский Н. М., 1964. Правописание наречий // Вопросы русской орфографии. М. : Наука. С. 43-50.

Щерба Л. В., 1957. О частях речи в русском языке // Избранные работы по русскому языку. М. : Учпедгиз. С. 63-84.

Wildgen W., 1990. Basic Principles of SelfOrganization in Language // Sinergetics of Cognition / ed. by H. M. Stadler. Berlin : Springer Verl. S. 415-426.

\section{СЛОВАРИ}

Гребенева Ю. Н. Морфемный словарь наречий русского языка. М. : Мир и Образование, 2017. $752 \mathrm{c}$.

Ефремова Т. Ф. Толковый словарь служебных частей речи русского языка. М. : Рус. яз., 2001. 863 с.

Толковый словарь русского языка с включением сведений о происхождении слов / отв. ред. Н. Ю. Шведова. М. : Азбуковник, 2007. 1175 с.

\section{REFERENCES}

Avdina A.I., 2013. Grammaticheskaya omonimiya kak spetsificheskoe yavlenie yazyka [Grammatical Homonymy as the Specific Language Phenomenon]. Vestnik Chelyabinskogo gosudarstvennogo pedagogicheskogo universiteta [Herald of Chelyabinsk State Pedagogical University], no. 9, pp. 204-211.

Akhmanova O.S., 1957. Ocherki po obshchey $i$ russkoy leksikologii [Essays on General and Russian Lexicology]. Moscow, Uchpedgiz Publ. 295 p.

Babaytseva V.V., 2000. Yavleniya perekhodnosti $v$ grammatike russkogo yazyka [Transitional Phenomena in the Grammar of Russian Language]. Moscow, Drofa Publ. 640 p.

Beshenkova E.V., 2016. Variativnost, uzualnaya norma i politika normalizatorov [Variants, Usual Way ofWriting, Codification and Policy of Orthographists].
Sibirskiy filologicheskiy zhurnal [Siberian Journal of Philology], no. 3,pp. 35-42. DOI: 10.17223/18137083/56/3.

Vinogradov V.V., 2001. Russkiy yazyk: (Grammaticheskoe uchenie o slove) [Russian Language (Grammatical Study of the Word)]. Moscow, Russkiy yazyk Publ. 720 p.

Voloshina T.A., 1994. Pravopisanie narechiy v russkom yazyke: istoriya i sovremennoe sostoyanie [Spelling of Adverbs in Russian: History and Current Status]. Rostov-on-Don, Izd-vo Rostovskogo gosudarstvennogo universiteta. $112 \mathrm{p}$.

Galkina-Fedoruk E.M., 1954. K voprosu ob omonimakh v russkom yazyke [To the Issue of Homonyms in Russian]. Russkiy yazyk v shkole, no. 3, pp. 14-19.

Krysin L.P., 2010. Problema sootnosheniya yazykovoy sistemy, normy i uzusa [Problem of the Correlation of the Linguistic System, Norm and Uzus]. Krysin L.P., ed. Sovremennyy russkiy yazyk: Sistema norma-uzus [Modern Russian Language: System Norm - Usage]. Moscow, Yazyki slavyanskikh kultur Publ., pp. 9-28.

Kuzmina S.M., 2010. Sistema, norma i uzus v fonetike i pisme [System, Norm and Usage in Phonetics and Writing]. Krysin L.P., ed. Sovremennyy russkiy yazyk: Sistema - norma - uzus [Modern Russian Language: System -Norm - Usage]. Moscow, Yazyki slavyanskikh kultur Publ., pp. 29-67.

Kurakov V.I., 1998. V plenu zabluzhdeniy, ili O nekotorykh protivorechiyakh $v$ teorii chastey rechi [In Captivity of Errors, or About Some Contradictions in the Theory of Parts of Speech]. Vestnik Volgogradskogo gosudarstvennogo universiteta. Seriya 2, Filologiya, pp. 92-94.

Lomonosov M.V., 1755. Rossiyskaya grammatika [Russian Grammar]. Saint Petersburg, Imperatorskaya Academiya nauk. 213 p.

Malakhovskiy L.V., 1990. Teoriya leksicheskoy $i$ grammaticheskoy omonimii [Theory of Lexical and Grammatical Homonymy]. Leningrad, Nauka Publ. 239 p.

Panov M.V., 1964. O slitnykh i razdelnykh napisaniyakh [About Merged and Separate Spelling]. Voprosy russkoy orfografii [Issues of Russian Spelling]. Moscow, Nauka Publ., pp. 100-119.

Pravila russkoy orfografii i punktuatsii [Rules of Russian Spelling and Punctuation], 1956. Moscow, Uchpedgiz Publ. $176 \mathrm{p}$.

Pravila russkoy orfografii i punktuatsii. Polnyy akademicheskiy spravochnik [Rules of Russian Spelling and Punctuation. Complete Academic Directory], 2006. Moscow, Eksmo Publ. 480 p.

Sidorova E.G., 2018. Problemy i protivorechiya kodifikatsii slozhnykh prilagatelnykh v russkom yazyke [Problems and Contradictions of Complex Adjectives Codification in the Russian Language]. Vestnik Volgogradskogo gosudarstvennogo universiteta. Seriya 2, Yazykoznanie [Science Journal of Volgograd 


\section{ДИСКУССИИ}

State University. Linguistics], vol. 17, no. 4, pp. 68-80. DOI: https://doi.org/10.15688/ jvolsu2.2018.4.6.

Kharchenko S.Yu., 2002. Protsess stanovleniya orfografii narechiy [Adverbs Spelling Process]. Vestnik Volgogradskogo gosudarstvennogo universiteta. Seriya 2, Yazykoznanie, no. 2, pp. 108-114.

Shanskiy N.M., 1964. Pravopisanie narechiy [Spelling of Adverbs]. Voprosy russkoy orfografii [Issues of Russian Spelling]. Moscow, Nauka Publ., pp. 43-50.

Shcherba L.V., 1957. O chastyakh rechi v russkom yazyke [On Parts of Speech in Russian]. Izbrannye raboty po russkomu yazyku [Selected Works in Russian]. Moscow, Uchpedgiz Publ., pp. 63-84.

Wildgen W., 1990. Basic Principles of SelfOrganization in Language. Stadler H.M., ed. Sinergetics of Cognition. Berlin, Springer Publ., pp. 415-426.

\section{DICTIONARIES}

Grebeneva Yu.N. Morfemnyy slovar narechiy russkogo yazyka [Morpheme Dictionary of Russian Adverbs]. Moscow, Mir i Obrazovanie Publ., 2017. $752 \mathrm{p}$.

Efremova T.F. Tolkovyy slovar sluzhebnykh chastey rechi russkogo yazyka [Explanatory Dictionary of Official Parts of the Speech of the Russian Language]. Moscow, Russkiy yazyk Publ., 2001.863 p.

Shvedova N.Yu., ed. Tolkovyy slovar russkogo yazyka s vklyucheniem svedeniy o proiskhozhdenii slov [Explanatory Dictionary of the Russian Language with the Inclusion of Information About the Origin of Words]. Moscow, Azbukovnik Publ., 2007. 1175 p.

\section{Information about the Author}

Svetlana Yu. Kharchenko, Candidate of Sciences (Philology), Associate Professor, Department of Russian Philology and Journalism, Volgograd State University, Prosp. Universitetsky, 100, 400062 Volgograd, Russia, xsvet@inbox.ru, https://orcid.org/0000-0001-9231-184X

\section{Информация об авторе}

Светлана Юрьевна Харченко, кандидат филологических наук, доцент кафедры русской филологии и журналистики, Волгоградский государственный университет, просп. Университетский, 100, 400062 г. Волгоград, Россия, xsvet@inbox.ru, https://orcid.org/0000-0001-9231-184X 